\title{
COVID-19 Metaforları: COVID-19 Pandemisinde Yaşlı Bireyler Üzerine Nitel Bir Araştırma
}

\author{
DOI: 10.26466/opus.936487
}

*

\author{
Mehtap Pekesen $^{*}$ - Şengül Akdeniz ${ }^{* *}$ \\ * Öğr. Gör. Dr., Akdeniz Üniversitesi, Sağlık Hizmetleri Meslek Yüksekokulu, Antalya/Türkiye \\ E-Posta: mehtappekesen@gmail.com \\ ORCID: 0000-0003-2193-1675 \\ ** Dr. Öğr. Üyesi, Akdeniz Üniversitesi, Sağlık Hizmetleri Meslek Yüksekokulu, Antalya/Türkiye \\ E-Posta: sengulakdeniz07@gmail.com \\ ORCID: $\quad \underline{0000-0002-4477-7159}$
}

Öz

Yaşlı bireylerin COVID-19 hastalık kavramına ilişkin risk algılarının belirlenmesi, morbidite ve mortalite açısından önemli bir psikososyal hedefi oluşturmaktadır. Araştırma COVID-19 pandemi sürecinde yaşl bireylerin kronik hastalığa sahip olma durumlarına göre "COVID-19" kavramına ilişkin algıları ve bu algilara sebep olabilecek nedenleri belirlemek amacıyla yapılmıştır. Bu nitel çalışma Türkiye'nin farklı bölgelerinde yaşayan 65 yaş ve üstü bireyler ile yapılmıştır. Araştırmaya amaçlı örneklem yöntemi olan kolay ulaşılabilir örnekleme yolu ile kronik hastalı̆̆ olan ve olmayan toplam 124 yaşlı birey dahil edilmiştir. Araştırma verileri 2020 yılı Haziran-Temmuz aylarında telefon görüşmesi yolu ile elde edilmiştir. Nitel veriler, araştırmacıların oluşturduğu metaforik alg formu aracılığı ile derinlemesine görüşme şeklinde toplanmıştır. Araştırmada yaşlı bireylerin "COVID-19" kavramına ilişkin algılarını, kronik hasta olma durumlarına göre kullandıkları zihinsel görüntüleri ve nedenlerini ortaya çıarmak amacıyla "COVID-19 ..... gibidir. Çünkü ....." cümlelerini tamamlamaları istenmiştir. Araştırmaya katılanların ürettikleri metaforlara bir gerekçe veya dayanak sağlamalar için "çünkü" kavramına yer verilmiştir. Bu çalışmanın sonuçları, dezavantajl gruplar olarak kabul edilen yaşh bireylerin pandemiyi nasıl algıladıkları, yönettikleri ve bu salgına karşı mücadeleye nasıl uyum sağladıkları konusunda ipuçları vermektedir. Araştırmada yaşlı bireylerin COVID-19'a ilişkin algilarının tehdit edici ve cesaret kırıcı şekilde olumsuz olduğu belirlenmiştir.

Anahtar Kelimeler: COVID-19, Metafor, Yaşlılık, Yaşlı, COVID-19 Metaforları. 


\title{
COVID-19 Metaphors: A Qualitative Study in Elderly Individuals in COVID-19 Pandemia
}

*

\begin{abstract}
Determining the risk perceptions of elderly individuals regarding the COVID-19 concept constitutes an important psychosocial goal in terms of morbidity and mortality. The research was conducted in order to determine the perceptions and reasons of the concept of "COVID-19" according to the chronic disease status of elderly individuals during the COVID-19 pandemic. This qualitative study was conducted with individuals aged 65 and over living in different regions of Turkey. A total of 124 elderly individuals with and without chronic disease were included in the study by means of easily accessible sampling, which is a purposeful sampling method. Research version obtained by telecommunication in June-July 2020. Qualitative data were collected in the form of in-depth interviews through the metaphorical perception form created by the researchers. In the study, revealing the perceptions of elderly individuals on the concept of "COVID-19" according to their chronic illness and its reasons is like "COVID-19 .... Because..." sentences were asked to complete. The concept of "because" was used to provide a justification or a basis for the metaphors produced by the participants in the research. These results give clues about how elderly individuals, who are regarded as disadvantaged groups, perceive and manage the pandemic and adapt to the fight against this epidemic. In the study, it was determined that the perceptions of elderly individuals regarding COVID-19 were negative as threatening and discouraging.
\end{abstract}

Key Words: COVID-19, Metaphor, Old Age, Elderly, COVID-19 Metaphors. 


\section{Giriş}

Tarihin en eski çağlarından beri kitlesel ölümlerin yaşandığı salgın hastalıkları metaforlar ile ilişkilendirme ve hatta tanımlama söz konusu olmuştur (Aykutalp 2021). Nitekim 21. yüzyılın en büyük sağlık krizi olan COVID-19 salgını, gündelik hayattan, politikacıların söylemine kadar uzanan bir dizi metafor ile tanımlanmaktadır (Aykutalp, 2021; Craig, 2020; MacLeod, 2021).

COVID-19 pandemi süreci, Susan Sontag'in "Metafor Olarak Hastalık" (1978) ve "AIDS ve Metaforları" (1989) adlı eserlerini tekrar gündeme getirmiştir (Craig, 2020; Güven, 2016). Eleştirel teorisyen Sontag, kanserden kurtulduktan sonra kaleme aldığı eserlerinde, salgınlara yönelik metaforik kullanımlarında efsaneleştirme eksenli sağlık-hastalık karşıtlığına dayanan "amansız hastalık" söylemlerine yer vermiş̧ir. Sontag eserlerinde tarihsel süreç tüberküloz ve kanser gibi hastalıklara ilişkin üretilen metaforların, hastalığın önüne geçtiğini ve hastalığı tanımladığını iddia etmektedir (Craig, 2020; Güven, 2016). Sontag, metafor yolu ile tanımlanan hastalığın sadece hastalık olarak değil aynı zamanda kötülükle, korkuyla, şeytanilikle, delilikle, tutkuyla, zenginlik ve yoksullukla, zamansal olarak yavaşlık ya da hızlılıkla ve yerle özdeşleştirilen bir olguya dönüştügünü ortaya koymaktadır (Sontag, 2005 akt. Aykutalp, 2021; Sontag, 1989 akt. Craig, 2020; Sontag, 1978 akt. MacLeod, 2021).

Tüm dünyayı hazırlıksız yakalayan ve COVID-19 hastalığına neden olan SARS CoV 2 virüsü, ilk olarak Aralık 2019 tarihinde Çin'in Vuhan şehri'nde tespit edildikten sonra hizlı bir şekilde tüm dünyaya yayılmıştır (WHO, 2021). COVID-19 yüksek bulaştırıcı özelliği, 65 yaş ve üzerindeki bireyler başta olmak üzere her yaş grubunda öldürücü olabilen klinik prognozu gerekçesi ile Dünya Sağlık Örgütü (WHO) tarafından 11 Mart 2020 tarihinde pandemi olarak ilan edilmiştir. Tüm dünyayı ve insanlığ fiziksel, ruhsal ve sosyal olarak tehdit altına alan COVID-19 pandemisi halen devam etmektedir (Budak ve Korkmaz, 2020). Bu tarihe kadar (22 Eylül 2021 tarihi itibariyle) COVID-19 nedenli ölümlerin sayısı küresel bazda 4.705.111 iken, ülkemizde bu sayı 59.384 olarak bildirilmiştir (WHO, 2021; T.C. Sağlık Bakanlığı, 2021). 
COVID-19 salgını, hükümetleri hastalığın etkisini en aza indirmek için sert halk sağlığı önlemleri almaya zorlamıştır. COVID-19 hastalığ her yaş grubunda görülebilmekle birlikte, ölümle sonuçlanan ilk vakaları çoğunlukla yaşlı nüfusun oluşturması dikkatleri yaşlıların üzerine çekmiştir (Daoust, 2020). Pandemi sırasında yaşlıları yüksek risk grubu altında tanımlayan en belirgin riskler ise; fizyolojik risk, kronik hastalık/ hastalıklara sahip olma, çoklu ilaç kullanımı ve artan ölüm oranları olmuştur. Ayrıca dolaylı riskler arasında; güvenlik eksikliği, yalnızlık, izolasyon, yaş ayrımcllığı, bağımlılık, damgalanma, istismar ve sağlık hizmetlerine erişimin kısıtlanması yer almaktadır. Yaşlı bireylerin hem salginın fizyolojik riskleri hem de mesafe ve izolasyonun psikososyal yan dallarına karşı mücadele ile karşı karşıya kaldığı görülmektedir (D'cruz ve Banerjee, 2020).

Küresel olarak pandemiye karşı mücadale devam ederken bir taraftan da tüm bunlara bir virüsün neden olması gerçeği, insanların "COVID19" kavramını sorgulamasına sebep olmuştur (WHO, 2021). Bu süreçte üst solunum yolu semptomları ile ortaya çıkan ve yüksek ölüm potansiyeline sahip olan COVID-19 hastalığı etkeni olan virüs hakkında farklı hipotezler geliştirilmiştir. Virüsün zoonotik yapıda olduğu, hayvanlardan insana geçtiği veya laboratuvar ortamında yapay veya kasıtlı olarak üretildiğine dair farklı bilgiler gündemdeki yerini almıştır (Üstün ve Özçiftçi, 2020). İnsanlar ise hala kendi bilgi dağarcığ 1 ölçüsünde COVID-19 kavramını zihninde anlamlandırmaya ve anlamaya çalışmaktadır.

İnsanların yeni bir kavramı anlamlandırmaya ilişkin algılarının, metafor aracılı̆̆ıyla tespit edilmesi yaygın bir kullanım olarak karşımıza çıkmaktadır (Aykutalp, 2021; Isaacs ve Priesz, 2020; MacLeod, 2021). Pandemi sürecinde dezavantajlı grup olarak nitelendirilen yaşlı bireylerin COVID-19 kavramına ilişkin zihinlerinde şekillendirdikleri algıların sorgulanması bu araştırmanın konusunu oluşturmaktadır. Araştırma kapsamında yaşlı bireylerin salgına yönelik fikirlerinin açı̆̆a çıkarılmasında araç olarak metaforlardan faydalanılmıştır.

Metafor bilinmeyen bir kavramla ilgili duygu ve düşünceyi algılama sürecidir. İnsanlar metafor yolu ile anlamaya ve yorumlamaya çalıştığı yeni kavramı nasıl algıladığını, eski bilindik bir bilişsel nesne ya da kavram üzerinden daha derinlemesine ifade edebilmektedir (Şahan, 
2017). Metafor kullanımı, hastalıktan mustarip kişilerin deneyimlerini ifade etmelerine imkan verirken, sağlık profesyonellerinin de metafor yolu ile hastalığın ve tedavinin çeşitli boyutlarını netleştirmelerini sağlamaktadır (Salıh Mohamed, 2021). Lakoff ve Johnson'a göre metaforlar yalnızca inançları, değerleri ve tutumları ifade etmekle kalmaz aynı zamanda, gelecekteki eylemlere yön verebilme potansiyeline sahiptir (Craig, 2020; Güven, 2016; Salih Mohamed, 2021). COVID-19 salgının da hastalık hakkında üretilen metaforların da hastalığın kendisine karşı verilecek mücadele hakkında açıklayıcı ve yön verici olacağı düşünülmektedir (Aykutalp, 2021; Craig, 2020; MacLeod, 2021).

COVID-19 hastalığını ifade eden metaforların edebiyattan sanata her alanda yaygın kullanıldığı ve gündelik söyleme dönüştüğü görülmektedir (Arapoğlu, 2020). Özellikle medya ve politik söylemlerde savaş metaforlarının yaygın kullanımı dikkat çekmektedir. Sağlık çalışanları için "beyaz ordu", "yüzleşmenin ön saflarında askerler", tıbbi maskeler için "silah" ve iyileşme için "hasta için bir zafer ve hastalık için yenilgi" şeklindeki metaforlar kullanılmaktadır (Salih Mohamed, 2021). Ancak Sontag'in salgın hastalıklardaki edebî ya da bilimsel söylemlerinin ayrımcılığı doğurduğu tezi unutulmamalıdır. Sontag "amansız hastalık" metaforlarının, zorunlu olarak ayrımc bir söylemi beraberinde getirdiğini, söze dayalı sanatların sağlı̆̆ı nasıl olumsuz etkileyebildiğini ve hatta insanların cesaretini kırabildiğini ortaya koymaktadır (Güven, 2016). Bu doğrultuda COVID-19 pandemi sürecinde dezavantajlı olan yaşlı bireylerin bu hastalığı nasıl algıladıklarının belirlenmesi, pandemi ile nasıl mücadele edeceklerini tayin etme potansiyeline sahip görünmektedir. Ancak literatür incelendiğinde COVID-19 pandemi sürecinde yüksek risk altında olduğu savunulan yaşlı bireylerin COVID-19 hastalık kavramına yönelik algılarını belirleyen bir araştırmaya rastlanmamıştır. Bu alandaki eksikliği gidermek bu araştırmanın çıkış noktasını oluşturmaktadır. COVID-19 pandemi sürecinde yaşlı bireylerin kronik hasta olma durumuna göre COVID-19 hastalık kavramını nasıl algıladıklarını ve nedenlerini metafor analizi aracılığı ile belirlemek bu araştırmanın amacını oluşturmaktadır. 
Araştırmada yaşlı bireylerin zihinlerinde COVID-19 hastalı̆̆ına yönelik oluşan algılarının metaforlar aracılığıyla ortaya çıkarılması amaçlanmış ve bu amaç doğrultuda aşağıdaki sorulara yanıt aranmıştır:

- Yaşlı bireylerin COVID-19'a yönelik metaforik algıları nelerdir?

- Yaşlı bireyler tarafından üretilen COVID-19 metaforları, benzerlik ve farklılıklarına göre hangi kavramsal kategoriler altında toplanabilir?

- Yaşlı bireylerin kronik hasta olma durumuna göre COVID-19 hastalığına yönelik metaforik algıları nelerdir?

\section{Yöntem}

\section{Araştırmanın Modeli ve Deseni}

$\mathrm{Bu}$ araştırma nitel araştırma modeli kapsamında olgubilim (fenomenoloji) deseni kullanılarak yapılmıştır. Nitel araştırma modeli, bireylerin bakış açılarının, algılarının, olayların gerçekçi ve bütüncül yaklaşım ile ortaya konmasına yönelik gözlem, görüşme ve doküman analizi şeklinde verilerin toplanması süreci olarak tanımlanmaktadır (Yıldırım ve Şimşek, 2018). Nitel araştırma modelinde kullanılan birçok desen bulunmakla birlikte bu araştırmada olgubilim (fenomenoloji) deseni tercih edilmiştir. Nitel araştırmaların temelinde katılımcıların deneyim ve bakış açılarına odaklanarak onların algı ve deneyimlerinin açığa çıkarılması yer almaktadır. Bu amaçla fenomenoloji deseni ile de katılımcıların yaşadıkları deneyimlerin anlamlandırılması yapılmaktadır (Creswell, 2020, s.72-98). Fenomenoloji bir grup bireyin ortak deneyimlerini vurgularken, günlük olarak sıklıkla karşılaştığımız ancak anlamını tam olarak kavrayamadı̆̆ımız olguları araştırmayı amaçlamaktadır (Creswell, 2020, s.72-98;Yıldırım ve Şimşek, 2018). Fenomenolojik araştırmalarda katılımcıların fenomene (bir kavram, bir düşünce ya da bir duygu) ilişkin bakış açıları ve algıları, fenomeni nasıl deneyimledikleri, nasıl anlamlandırdıkları ve nasıl betimledikleri üzerine odaklanılmaktadır. Fenomenoloji deseninde genelleme yapmak değil, fenomeni tanımlamak ve kişisel deneyimlere dayalı sonuçları belirlemek önemlidir (Tekindal ve Uğuz Arsu, 2020). Bu araştırmada yaşlı bireylerin COVID-19 hastalık kavramına ilişkin bakış açıları ve 
algilarını metaforlar yoluyla tespit etmek amacıyla fenomenoloji deseni tercih edilmiştir.

\section{Araştırma Grubu}

Araştırma, pandemi gerçeğini göz önünde bulundurma ve araştırma katılımclarını herhangi bir risk almamaları prensibi temel alınarak, koruma tedbirleri kapsamında gerçekleşmiştir. $\mathrm{Bu}$ amaçla kendi evlerinde yaşayan yaşlı bireyler ile telefon görüşmesi aracılı̆̆ı ile görüşmeler yapılmıştır. Türkiye'nin farklı bölgelerinde yaşayan Yaşlı Bakım Programı son sınıf öğrencileri, çevrelerinde iletişim halinde oldukları yaşlı bireyler ile ön görüşmelerin yapılması ve araştırmaya katılmaya gönüllü olan kriterlere uygun katılımcıların belirlenmesi konusunda araştırmaya katkı sağlamışlardır. Örneklem seçiminde, amaçlı örnekleme yöntemlerinden kolay ulaşılabilir örnekleme kullanılmış ve örneklem büyüklüğü hesabı yapılmadan "doygunluk" noktasına ulaşana kadar veriler toplanmaya devam edilmiştir.

\section{Araştırmaya Dahil Edilme Kriterleri}

- COVID-19 hastalık tanısı almamış yaşlı bireyler

- Telefon görüşmesine ve soruları cevaplamaya işitme problemi gibi herhangi bir engeli olmamak,

- 65 yaş ve üstü olmak,

- Araştırmayı kabul eden bireyler çalışmaya alınacaktır.

\section{Araştırmaya Dahil Edilmeme Kriterleri}

- 65 yaşından küçük olmak,

- Araştırmaya katılmayı kabul etmemek,

- Herhangi bir mental problem ya da konuşma ve dinleme gibi bir engele sahip olmak 


\section{Katılımcılara İlişkin Tanımlayıcı Bulgular}

Araştırma kapsamına giren 124 yaşlı bireyin \% 41,1'i 65-74 yaş grubunda, \%50'si 75-84 yaş grubunda ve \% 8,9'u 85 yaş ve üzerindedir. Katılımciların \%59,7'si kadın, \%56,5'i evli, \%16,1'i okuma yazma bilmiyor, \%58,1'i ev hanımı, \%13,7'si halen çalışmakta olup, \%26,6'sının sosyal güvencesi yok, $\% 20,2$ 'si yalnız yaşamakta, $\% 33,9^{\prime}$ unun ortalama aylık geliri asgari ücretin altındadır. Yaşlıların \%75,8'inin en az bir kronik hastalığı bulunmaktadır. Bu hastalıkların başında; \%52,4 ile hipertansiyon, \%46,8 ile diabetes mellitus ve \%20,2 ile romatizmal hastalıklar gelmektedir. Yaşlı bireylerin \%55,6'sının her gün düzenli olarak içtiği bir ilaç bulunmaktadır. Katılımcıların nörolojik veya psikiyatrik hastalık tanısı bulunmamaktadır. Ayrıca araştırma katılımclarında araştırma verilerinin toplandığı tarihe kadar, COVID-19 pozitif olgu durumu bildirilmemiştir.

\section{Verilerin Elde Edilmesi}

Araştırma verileri aynı araştırmacı tarafından Haziran-Temmuz 2020 tarihlerinde yapılan derinlemesine görüşme yöntemi ile elde edilmiştir. Veriler araştırmacılar tarafından geliştirilen katılımcılara ilişkin bilgi formu ve metaforik algı formu aracılı̆̆ı ile toplanmıştır. Katılımcıların metaforik algılarının belirlenmesinde metafor formları, veri toplama aracı olarak kullanılabilmektedir (K1lcan, 2017, s.13). Araştırmada COVID-19 pandemi sürecinde yaşlı bireylerin COVID-19 hastalığ1 hakkında alg1 ve farkındalıklarını, kronik hasta olma durumlarına göre kullandıkları zihinsel görüntüleri ve nedenlerini ortaya çıkarmak amacıyla "COVID-19 ... gibidir. Çünkü ..." cümlelerini tamamlamaları istenmiştir. Araştırmaya katılanların ürettikleri metaforlar için bir gerekçe veya mantıksal dayanak sağlamaları için "çünkü" kavramına yer verilmiştir (Kılcan, 2017, s.13) Görüşmelerin tamamı katılımcılara araştırma hakkında bilgi verildikten ve onayı alındıktan sonra gerçekleşmiştir. Görüşmelerin her biri yaklaşık 15 dakika (10-20dk) sürmüştür. Görüşme yapılan her bir katılımcıya ayrı bir kod numarası verilerek ses kayıtları alınmıştır. Verilerin analizi sırasında 
katılımcların isimleri yerine görüşmeler sırasında belirlenen kodlar (G1,....G125) kullanılmıştır.

\section{Verilerin analizi}

Araştırma verilerinin analizinde SPSS 21 paket programından yararlanılmıştır. Araştırma verileri görüşmelerin hemen bitiminde yazıya dökülerek transkriptleri hazırlanmıştır. Araştırmada elde edilen verilerin analizinde içerik analizinden faydalanılmıştır. İçerik analizi, birbirine benzeyen verileri kavramsal olarak ifadelere dönüştürmek (kodlar) ve bu kavramlar arasındaki ilişkilere (temalar) ulaşmaktır (Yıldırım ve Şimşek, 2018).

Araştırma kapsamında yaşlı bireylerden elde edilen veriler analiz edilirken öncelikli olarak metafor formları incelenmiş ve kontrol edilmiştir. Metafora ilişkin herhangi bir mantıksal dayanağın ya da gerekçenin sunulmadığı, COVID-19 hastalığ 1 algısının anlaşılmasına katkı sağlamayacağı düşünülen 18 adet görüşme araştırmaya dahil edilmemiştir. Araştırmada metafor özelliği gösteren 106 form tekrar okunarak incelenmiştir ve her bir form numaralandırılmıştır. İki araştırmacı tarafından numara sırasına göre düzenlenen metaforlar sesli olarak okunmuş ve benzer anlamları ifade eden metaforlar bir araya getirilmiştir. Tüm metaforların yer aldığı genel bir frekans tablosu hazırlanmıştır. Sonraki aşamada benzer özellikleri esas alınarak üretilen metaforlar katılımcıların sunmuş olduğu gerekçeler doğrultusunda araştırmacılar tarafından kategorize edilmiştir.

Ayrıca metaforların temsil ettiği özellikler doğrultusunda kavramsal kategorileri ve yaşlı bireylerin kronik hasta olup-olmama değişkenine göre frekans değerleri hesaplanarak bir metafor tablosu oluşturulmuştur. Araştırma verilerinin SPSS 21 paket programında Frekans (f) ve oran (\%) değerleri hesaplanmıştır. Bulgularda kategorilerde yer alan metaforlara yönelik katılımcı cümlelerine de yer verilmiştir. Analiz sürecinde metafor formlarına yönelik yapılan numaralandırma işlemi yaşlı bireylerin sıralamasını temsil edecek biçimde ele alınmıştır (G1 ... G106).

Araştırmada aynı verileri farklı araştırmacıların yorumlaması, analiz etmesi ve kıyaslaması, güvenirliğin sağlanması açısından önemlidir. Araştırmanın tutarlılı̆̆ını ve anlaşılmasını arttırmak amacı ile 
araştırmada yer almayan başka bir alan uzmanı tarafından oluşturulan kodlar arasında uzlaşı olup olmadığına bakması ve hiçbir metafor dışarıda bırakılmayacak biçimde kavramsal kategorileri eşleştirmesi istenmiştir. Alan uzmanı ile araştırmacıların yapmış olduğu eşleştirmeler karşılaştırılmış ve görüş birliği ve ayrılığı sayıları tespit edilmiştir. Oluşturulan kavramsal kategorileri için güvenirlik hesaplaması Miles ve Huberman'ın güvenirlik formülü kullanılarak hesaplanmıştır. Güvenirlik için değerin en az 80 olması gerekmekte iken; bu araştırmada Güvenirlik=görüş birliği/(görüş birliği+görüş ayrllığı) formülü ile hesaplamalara göre $(41 /(41+8) \times 100=84) \% 84$ oranında bir uzlaşma sağlandığı hesaplanmıştır (Miles ve Huberman, 2016).

\section{Araştırmanın Etik Boyutu}

$\mathrm{Bu}$ araştırma Helsinki Bildirgesi'nin (2016) ilkelerine göre yapılmış ve ayrıca yaşlı bireylere gizlilik ilkesinin çiğnenmeyeceği, elde edilen verilerin bilimsel araştırma dişında diğer amaçlarla asla kullanılmayacağı ve kimliklerinin gizleneceği konusunda güvence verilmiştir. Araştırmanın etik onayı TC Sağlık Bakanlığı ve Akdeniz Üniversitesi Tip Fakültesi Klinik Araştırmalar Etik Kurulu'ndan (19.06.2020 tarihli ve 70904504/376 sayılı 2012-KAEK-20 kodu) izin alınmıştır.

\section{Araştırmanın Sınırlılıkları}

Araştırmada nitel araştırma deseni kullanılmıştır. Araştırma sonuçları literatürle uyumlu olmakla birlikte, bu kanıt nitel çalışmaların doğası gereği çalışma grubu için geçerlidir ve genellenemez. Araştırmaya yansıyan perspektif sınırlıdır çünkü derinlemesine görüşmeler telefon yoluyla gerçekleştirilmiştir ve gözlemsel boyut değerlendirilememiştir. Araştırma verileri sözlü ifadelere dayalı olarak elde edilmiştir. Bu nedenle, katılımcıların acı verici deneyimlerini hatırlamasında ve onlara verdiği tepkilerde önyargı olabilir. 


\section{Bulgular}

Araştırma bulguları araştırma alt problemleri doğrultusunda üç bölümde ele alınmıştır. Bunlar sırasıyla; yaşlı bireylerin COVID-19 hastalığına yönelik oluşturdukları metaforlar, yaşlı bireylerin oluşturdukları metaforlara ilişkin kavramsal kategoriler ve yaşlı bireylerin kronik hasta olma durumuna göre oluşturdukları metaforlar şeklinde açıklanmıştır.

Yaşlı Bireylerin COVID-19 Hastahı̆ına Yönelik Metaforik Algıları: Araştırmada elde edilen bulgular sonucunda yaşlı bireyler tarafından "COVID-19" kavramına ilişkin 41 geçerli metafor üretildiği saptanmıştır. Ayrıca katılımcı sayısına göre metafor algisı hesaplanarak, metafora ait frekans değerleri belirlenmiştir. Araştırmada yer alan 124 katılımcının üretmiş oldukları metaforlar incelenirken; 106 katılımcının $(\% 85,5)$ COVID-19 salgınına ilişkin algılarını metafor yoluyla açıklayabildikleri, 18 katılımcının (\%15) ise metafor yoluyla açıklayamadığı belirlenmiştir. Dolayısıyla metafor özelliği göstermeyen 18 adet veri çalışma dişında bırakılmıştır.

Yaşlı bireylerin COVID-19 hastalığına yönelik üretmiş oldukları metaforlar ve frekans değerleri Tablo 1'de sunulmuştur.

Tablo 1. Yaşlı Bireylerin COVID-19 Hastalığına İlişkin Oluşturdukları Metaforlar

\begin{tabular}{|c|c|c|c|c|c|}
\hline No & Metafor & Frekans (f) & No & Metafor & Frekans (f) \\
\hline 1 & Mikrop & 8 & 21 & Verem & 2 \\
\hline 2 & Ölüm & 7 & 22 & Karanlık & 1 \\
\hline 3 & Görünmeyen Düşman & 5 & 23 & Biyolojik Terörist & 1 \\
\hline 4 & Ceza & 5 & 24 & Uçan Akrep & 1 \\
\hline 5 & Boğulma & 5 & 25 & İflas & 1 \\
\hline 6 & Ecel Sinav1 & 4 & 26 & Yangin & 1 \\
\hline 7 & Öksürük & 4 & 27 & Tehlikeli Diken & 1 \\
\hline 8 & Kiyamet & 4 & 28 & Hirsiz & 1 \\
\hline 9 & Öldürücü Grip & 4 & 29 & Firtına & 1 \\
\hline 10 & Silah & 4 & 30 & Kanser & 1 \\
\hline 11 & Ölüm Makinesi & 4 & 31 & Yok Edici & 1 \\
\hline 12 & Şeytan & 4 & 32 & Ç1ğ Düşmesi & 1 \\
\hline 13 & Zehir & 4 & 33 & İnsan Kapanı & 1 \\
\hline 14 & Hapislik & 4 & 34 & Miknatıslı Virüs & 1 \\
\hline 15 & Öğretmen & 3 & 35 & Körlük & 1 \\
\hline 16 & İstila & 3 & 36 & Komutan & 1 \\
\hline 17 & Cüzzam & 3 & 37 & Veba & 1 \\
\hline 18 & Bomba & 3 & 38 & Gezgin & 1 \\
\hline 19 & Afet & 3 & 39 & Kabus & 1 \\
\hline \multirow[t]{2}{*}{20} & Katliam & 3 & 40 & Arınma & 1 \\
\hline & & & 41 & Disiplin Cezası & 1 \\
\hline
\end{tabular}


Tablo 1 incelendiğinde, yaşlı bireylerin COVID-19 hastalığına ilişkin olarak toplamda 41 farklı metafor üretmiş oldukları görülmektedir. Bu üretilen metaforlardan katılımcıların en sık kullandıkları metaforlar sırasiyla: "Mikrop (f:8)”, “Ölüm (f:7)”, “Görünmeyen Düşman (f:5)”, “Ceza (f:5)”, “Boğulma (f:5)”, “Sinanma/Ecel Sinavı (f:4)”, “Öksürük (f:4)", "Kiyamet (f:4)", “Öldürücü Grip (f:4)”, "Silah (f:4)”, “Ölüm Makinesi (f:4)", "Şeytan (f:4)", “Zehir (f:4)”, “Hapislik (f:4)”, “Öğretmen (f:3)”, “İstila (f:3)”, “Cüzzam (f:3)”, “Bomba (f:3)”, “Afet (f:3)”, “Katliam (f:3) şeklinde ifade edilmiştir. Yaşlı bireylerin COVID-19 salgınına ilişkin olarak ürettikleri metaforlar incelendiğinde, üretilen metaforların çoğunun salgının hızlı bir şekilde yayılmasıyla ve öldürücülük özelliği ile ilişkilendirildiği görülmektedir.

\section{Yaşlı Bireylerin COVID-19 Hastalı̆̆ına İlişkin Oluşturdukları} Metaforlara İlişkin Kavramsal Kategorileri: Yaşlı bireyler tarafından COVID-19 hastalığına ilişkin üretilmiş olan 41 farklı metafor değerlendirilmiştir. Değerlendirme sonrasında benzer özelliklere işaret eden metaforlar tekrardan incelenerek kategorize edilmiştir. Bu bağlamda yaşlı bireylerin COVID-19'a yönelik üretmiş oldukları metaforlar sırasıyla "Sağlıklı Yaşamı Tehdit Eden Olumsuz Unsur ile İlişkilendirme", "Savaş Unsuru ile İlişkilendirme", "Spiritüel Bakış Algısı ile İlişkilendirme", "Diğer Hastalıklar ile İlişkilendirme", "COVID-19 Belirtileri ile İlişkilendirme" "Doğa Olayları ile İlişkilendirme", "Öğreticilik ve Eğitim ile İlişkilendirme" ve "Diğer Canlılar ile İlişkilendirme" olmak üzere toplam 8 kategori altında gruplandırılarak kategorize edilmiştir. Yaşlı bireylerin COVID-19 salgına yönelik oluşturdukları metaforlara ilişkin kavramsal kategoriler Tablo 2'de sunulmuştur. 
Tablo 2. Yaşlı Bireylerin COVID-19 Hastalığına İlişkin Oluşturdukları Metaforlara İlişkin Kavramsal Kategoriler

\begin{tabular}{|c|c|c|c|c|c|}
\hline \multirow[t]{2}{*}{ Metafor Kategorisi } & \multirow[t]{2}{*}{ Metaforlar } & \multicolumn{2}{|c|}{ Yaşl1 Birey } & \multicolumn{2}{|c|}{ Metafor } \\
\hline & & (f) & $(\%)$ & (f) & $(\%)$ \\
\hline $\begin{array}{l}\text { Sağlıklı Yaşamı Tehdit } \\
\text { Eden Olumsuz Unsur ile } \\
\text { Illişkilendirme }\end{array}$ & $\begin{array}{l}\text { Mikrop (8), Ölüm (7), Şeytan (4), } \\
\text { Zehir (4), Hapislik (4), Karanlık } \\
\text { (1), İflas (1), Yangın (1), Hırsız } \\
\text { (1), Mıknatıslı Virüs (1), Kabus } \\
\text { (1), Hastalık Taşıyan Gezgin (1), } \\
\text { Körlük (1) }\end{array}$ & 35 & 33 & 13 & 31,7 \\
\hline $\begin{array}{l}\text { Savaş Unsuru ile } \\
\text { İlişkilendirme }\end{array}$ & $\begin{array}{l}\text { Görünmeyen Düşman (5), } \\
\text { Silah (4), Ölüm Makinesi (4), } \\
\text { İstila (3), Bomba (3), Katliam } \\
\text { (3), Biyolojik Terörist (1), } \\
\text { Yok Edici (1), İnsan Kapanı } \\
\text { (1), Komutan (1) }\end{array}$ & 26 & 24,5 & 10 & 24,4 \\
\hline $\begin{array}{l}\text { Spiritüel Bakış Algısı ile } \\
\text { İlişkilendirme }\end{array}$ & $\begin{array}{l}\text { Ceza (5), Sınanma/Ecel } \\
\text { sinavı (4), Kıyamet (4), } \\
\text { Arınma (1) }\end{array}$ & 14 & 13,2 & 4 & 9,8 \\
\hline $\begin{array}{l}\text { Diğer Hastalıklar ile } \\
\text { Ilişkilendirme }\end{array}$ & $\begin{array}{l}\text { Öldürücü Grip (4), Cüzzam } \\
\text { (3), Verem (2), Kanser (1), } \\
\text { Veba (1) }\end{array}$ & 11 & 10,4 & 5 & 12,2 \\
\hline $\begin{array}{l}\text { COVID-19 Belirtileri ile } \\
\text { İlişkilendirme }\end{array}$ & Boğulma (5), Öksürük (4) & 9 & 8,5 & 2 & 4,9 \\
\hline $\begin{array}{l}\text { Doğa Olayları ile } \\
\text { İlişkilendirme }\end{array}$ & $\begin{array}{l}\text { Afet (3), Fırtına (1), Çı̆̆ } \\
\text { Düşmesi (1) }\end{array}$ & 5 & 4,7 & 3 & 7,3 \\
\hline $\begin{array}{l}\text { Öğreticilik ve Eğitim ile } \\
\text { Illişkilendirme }\end{array}$ & $\begin{array}{l}\text { Öğretmen (3), Disiplin } \\
\text { Cezası (1) }\end{array}$ & 4 & 3,8 & 2 & 4,9 \\
\hline $\begin{array}{l}\text { Diğer Canlılar ile } \\
\text { İlişkilendirme }\end{array}$ & $\begin{array}{l}\text { Uçan Akrep (1), Tehlikeli } \\
\text { Diken (1) }\end{array}$ & 2 & 1,9 & 2 & 4,9 \\
\hline Toplam & & 106 & 100 & 41 & 100 \\
\hline
\end{tabular}

Tablo 2'de COVID-19'a ilişkin ifade edilen metafor kategorileri, kategorilerde yer alan metafor ve katılımcı sayıları yer almaktadır. Aşağıda yaşlı bireyler tarafından COVID-19 hastalığına ilişkin ifade edilen ilgili metaforlar ve metafor örnekleri ile birlikte kategoriler yer almaktadır. 
Kategori 1: Sağlıklı Yaşamı Tehdit Eden Olumsuz Unsur ile İlişkilendirme: COVID-19'a ilişkin oluşturulan ifadelerin yer aldığı bu kategoride 35 (\%33) katılımcı tarafından toplam 13 (\%31,7) metafor üretilmiştir. Üretilen metaforlar; Mikrop (f:8), Ölüm (f:7), Şeytan (f:4), Zehir (f:4), Hapislik (f:4), Karanlık (f:1), İflas (f:1), Yangın (f:1), Hırsız (f:1), Mıknatıslı Virüs (f:1), Kabus (f:1), Hastalık Taşıyan Gezgin (f:1) ve Körlük (f:1) şeklinde siralanmaktadır. Bu kategoride COVID-19 hastalığına ilişkin oluşturulan metaforlara ait örnek ifadeler aşağıda verilmiştir:

"COVID-19 mikrop gibidir. Çünkü aynı mikroplar gibi insanları hayvanları hasta ediyor. Mikrop gibi zarar veriyor" (G9)

"COVID-19 ölüm gibidir. Çünkü dediklerine göre ölmekten farkı yok ya öldürüyor ya ölmekten beter ediyor" (G21)

"COVID-19 şeytan gibidir. Çünkü bir nevi şeytan gibi görünmeden insanın iliklerine kadar girip şeytan gibi zarar veriyor" (G82)

"COVID-19 zehir gibidir. Çünkü zehir içmişten beter ediyor adamı

Aynı zehir bir farkı yok... Öldürüyor" (G104)

"COVID-19 hapislik gibidir. Çünkü bu lanet şey çıktığından beri hapislik yaşıyoruz. Hasta olan hastane de olmayan evde hapis. Hapislik gibi yani bir farkı yok" (G13)

"COVID-19 karanlık gibidir. Çünkü karanlık gibi ne olduğu belli değil... Bilmiyoruz ne olduğunu. Doktorlar bile kesin şu şöyledir diyemiyor hala..." (G78)

"COVID-19 iflas gibidir. Çünkü ayn iflas eden iş yeri ya da esnaf gibi vücudun iflas ediyor diyorlar. Tüm vücudu tüketiyormuş " (G32)

"COVID-19 yangın gibidir. Çünkü bu hastalık girdiği evi ya da insanı ayn yangin misali yakıyor, yok ediyor" (G69)

"COVID-19 hırsız gibidir. Çünkü ayn hırsız gibi insana gizlice girip hayatını çalıyor " (G50)

"COVID-19 mıknatıslı virüs gibidir. Çünkü bulduğu her şeye mıknatıs gibi yapışan bir virüs" (G44)

"COVID-19 kabus gibidir. Çünkü kabus gibi insanlara ecel terleri döktürüyor. Korkutuyor..." (G30)

"COVID-19 hastalık taşıyan gezgin gibidir. Çünkü gezginler öyledir dă̆ taş demeden gezer. Bu virüs de öyle. 'O ülke senin bu ülke benim' demiyor. Geziyor milleti kırtp dökerek

$"$ (G57) 
“COVID-19 körlük gibidir. Çünkü nasıl ki kör olduğunda önünü göremezsin bir sonraki adımında neye çarpacağın kestiremezsin bu virüste öyle işte. Hem göremiyorsun hem de ne olacağın kestiremiyorsun. Kör olmuş gibi bekliyoruz" (G3)

Kategori 2: Savaş Unsuru ile İlişkilendirme: COVID-19 Hastalığına ilişkin oluşturulan ifadelerin yer aldığı bu kategoride $26(\% 24,5)$ katılımcı tarafından toplam $10(\% 24,4)$ metafor üretilmiştir. Üretilen metaforlar; Görünmeyen Düşman (f:5), Silah (f:4), Ölüm Makinesi (f:4), İstila (f:3), Bomba (f:3), Katliam (f:3), Biyolojik Terörist (f:1), Yok Edici (f:1), İnsan Kapanı (f:1) ve Komutan (f:1) şeklinde sıralanmaktadır. Bu kategorideki metaforlara ilişkin örnek ifadeler aşağıda verilmiştir:

"COVID-19 görünmeyen düşman gibidir. Çünkü COVID-19 da tıpkı görünmeyen düşman misali nereden geleceği kimden bulaşacă̆̆ belli olmayan tehlike" (G28)

"COVID-19 silah gibidir. Çünkü silahta insanı ya öldürür ya sakat bırakır sonuçta mutlaka bir zarar verir" (G13)

“COVID-19 ölüm makinesi gibidir. Çünkü ölüm makinesi gibi insanları hızlı hızlı öldürmeye komutlanmış sanki..." (G7)

"COVID-19 istila gibidir. Çünkü istila da ayn COVID-19 gibi bir yeri istila etmek yerle bir etmek ele geçirmek anlamina geliyor. Bu virüs istilaya benziyor" (G54)

"COVID-19 bomba gibidir. Çünkü bomba patladığı yeri yok eder" (G84)

"COVID-19 katliam gibidir. Çünkü katliamda toplu insan ölümleri olur" (G12)

"COVID-19 biyolojik terörist gibidir. Çünkü terör sadece silahlı insanla olmaz bu virüste bir nevi laboratuvarda hazırlanmış terörist" (G24)

"COVID-19 yok edici gibidir. Çünkü yok edici de önüne geleni ayırt etmeden yok eder adam seçmez" (G67)

"COVID-19 insan kapanı gibidir. Çünkü insanı tuzağa düşürmek için kurulan kapan misali yakalanan kaçamıyor, kurtulamıyor" (G2)

"COVID-19 komutan gibidir. Çünkü komutan nasıl emir verirse komut ettiği askerler o emre uyar. COVID-19' da bütün dünyaya komutanlık ediyor, bizi yönetiyor" (G91) 
Kategori 3: Spiritüel Bakış Algısı ile İlişkilendirme: COVID-19 Hastalığına ilişkin oluşturulan ifadelerin yer aldığ1 bu kategoride 14 $(\% 13,2)$ katılımc tarafından toplam $4(\% 9,8)$ metafor üretilmiştir. Üretilen metaforlar; Ceza (f:5), Sinanma/Ecel sinavı (f:4), Kiyamet (f:4), Arınma (f:1) şeklinde siralanmaktadır. Bu kategorideki COVID-19 Hastalığına ilişkin metafor örnek ifadeleri aşağıda verilmiştir:

“COVID-19 ceza gibidir. Çünkü ceza da Hak yolundan çıkan kullarına Rabbim'in verdiği Hak'tır. Bu virüs yolunu şaşırmış insanlara ceza" (G1)

"COVID-19 sinanma gibidir. Çünkü sinanma bu dünyadaki insanların ecel sinavr yani tam da böyle sinar insanın iman gücünü" (G29)

"COVID-19 kıyamet gibidir. Çünkü dünyanın sonu gelmiştir ve bütün ruhların mahşerde toplanıp hesap verme zamanıdır" (G86)

"COVID-19 arınma gibidir. Çünkü arınma temizlenmek, tüm kötü alışkanlıkları ve günahı bırakmaktır. Bu hastalık tüm dünyayı arındırıyor kah öldürerek kah günahlardan uzak tutarak" (G10)

Kategori 4: Diğer Hastalıklar ile İlişkilendirme: Bu kategoride 11 $(\% 10,4)$ katılımcı tarafından toplam $5(12,2)$ metafor üretilmiştir. Bu metaforlar sırasıyla; Öldürücü Grip (f:4), Cüzzam (f:3), Verem (f:2), Kanser (f:1), Veba (f:1) şeklinde belirlenmiştir. COVID-19 Hastalığına ilişkin bu kategoride oluşturulan metaforlara ilişkin örnek ifadeler aşağıda verilmiştir:

“COVID-19 öldürücü grip gibidir. Çünkü öldürücü grip de hapşırık aksırık ile insanlardan bulaşır basit başlar ama ölüme götürür" (G81)

"COVID-19 cüzzam gibidir. Çünkü cüzzam da dokunma ile bulaşır ve cüzzamlı insandan da herkes uzak durur..." (G96)

"COVID-19 verem gibidir. Çünkü verem de aynı havayı soluduğun insana geçer. Bulaşıcıdır" (G47)

“COVID-19 kanser gibidir. Çünkü kanser de öldürücü ya da süründüren kötü hastalıktır" (G8)

“COVID-19 veba gibidir. Çünkü veba insanları ve hayvanları kırıp geçiren tehlikeli, öldürücü bir salgındır" (G53)

Kategori 5: COVID-19 Belirtileri ile İlişkilendirme: Bu kategoride 9 $(\% 8,5)$ katılımcı tarafından toplam $2(\% 4,9)$ metafor üretilmiştir. Üretilen metaforlar; Boğulma (f:5), Öksürük (f:4) şeklinde belirlenmiştir. Bu 
kategori altında katılımcıların belirtmiş oldukları metaforlara ilişkin örnek ifadeler aşağıdaki gibidir:

"COVID-19 boğulma gibidir. Çünkü boğulan canlı nefes alamaz can çekişir, çırpınır durur nefes için..." (G35)

"COVID-19 öksürük gibidir. Çünkü öksürük sırasında ciğerlerin ağzına gelir gibi olur, ne konuşabilirsin, ne nefes alabilirsin... Ta ki bitene kadar" (G72)

Kategori 6: Doğa Olaylan ile İlişkilendirme: Bu kategoride 5 (\% 4,7) katılımcı tarafından toplam $3(7,3)$ metafor üretilmiştir. Bu metaforlar sırasıyla; Afet (f:3), Fırtına (f:1), Çı̆̆ Düşmesi (f:1) şeklinde belirlenmiştir. Bu kategori altında katılımcıların belirtmiş oldukları metaforlara ilişkin doğrudan alıntı örnek ifadeleri aşağıdaki gibidir:

"COVID-19 afet gibidir. Çünkü afetlerde tüm dünyayı yerle bir eder" (G70) "COVID-19 firtına gibidir. Çünkü fırtınadan kaçış mümkün değildir" (G4)

"COVID-19 çı̆̆ düsşmesi gibidir. Çünkü çı̆̆ düştüğünde apansız yakalanır, altında ezilirsin. Çıkamazsın. Kurtuluşun zor olur" (G58)

Kategori 7: Öğreticilik ve Ĕgitim ile İlişkilendirme: Bu kategoride 4 $(\% 3,8)$ katılımcı tarafindan toplam $2(4,9)$ metafor üretilmiştir. Bu metaforlar; Öğretmen (f:3), Disiplin Cezası (f:1) şeklinde belirlenmiştir. Katılımcıların bu kategori altında belirtmiş oldukları metaforlara ilişkin doğrudan alıntı örnek cümleleri aşağıdaki gibidir:

"COVID-19 öğretmen gibidir. Çünkü öğretmen öğretici, eğitici, terbiye edicidir. Yol göstericidir" (G106)

"COVID-19 disiplin cezası gibidir. Çünkü disiplin cezası söz dinlemeyen yaramazlara verilir" (G63)

Kategori 8: Diğer Canlılar ile İlişkilendirme: COVID-19 Hastalığına ilişkin oluşturulan ifadelerin yer aldığı bu kategoride $2(\% 1,9)$ katılımc1 tarafından toplam $2(\% 4,9)$ metafor üretilmiştir. Üretilen metaforlar; Uçan Akrep (f:1), Tehlikeli Diken (f:1) şeklinde belirlenmiştir. Katılımcıların bu kategori altında belirtmiş oldukları metaforlara ilişkin örnek ifadeler aşağıdaki gibidir:

“COVID-19 uçan akrep gibidir. Çünkü akrebin uçanı olsaydı tıpkı bu virüs gibi ansızın içimize kadar girip bize zarar verirdi" (G42) 
“COVID-19 tehlikeli diken gibidir. Çünkü dikenin tehlikeli olanı battığı anda insana zarar verir, can yakar ve yapışır insana çıkarmak zordur" (G105)

\section{Yaşlı Bireylerin Kronik Hasta Olma Durumuna Göre Oluşturdukları COVID-19 Metaforlarına İlişkin Bulgular}

Yaşlı bireylerin kronik hasta olma değişkenine göre COVID-19 hastalığına ilişkin oluşturdukları metafor ve kavramsal kategorilerin dağglımları Tablo 3'de verilmiştir.

Tablo 3. Yaşlı Bireylerin Kronik Hasta Olma Durumuna Göre Oluşturdukları COVID-19 Metaforları ve Kavramsal Kategorileri

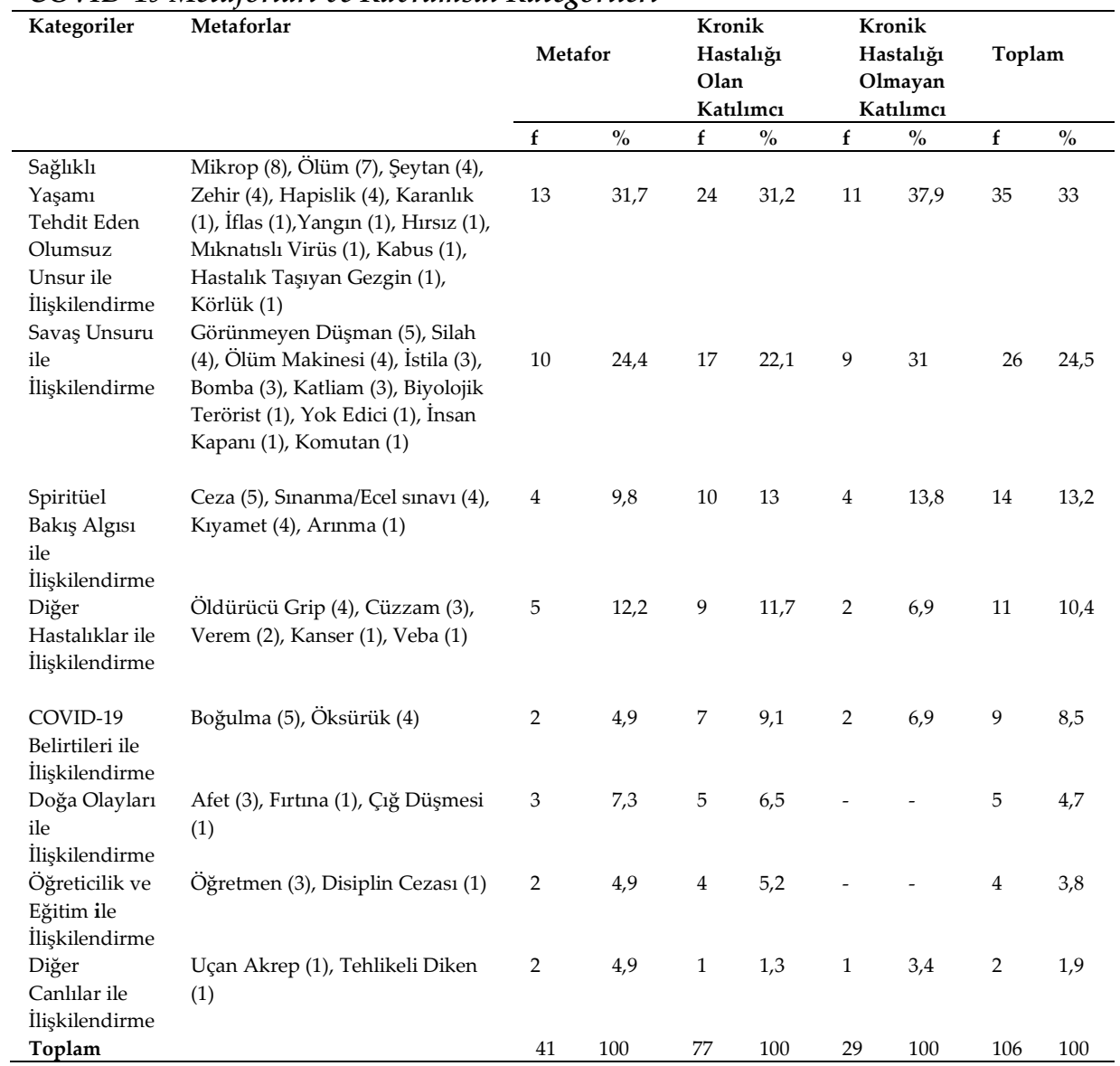


Tablo 3'e göre COVID-19 hastalığ metaforlarında ilgili kategorilerde yer alan yaşlı bireylerin kronik hasta olma değişkenine göre dağılımına bakıldığında kronik hastalığı olan ve olmayan katılımcıların ilk sıralarda yer alan kategoriler arasında fark bulunmamaktadır. Bu kategoriler sırasıyla; sağhlkh yaşamı tehdit eden olumsuz unsur ile ilişkilendirme (kronik hastalığı olan\%31,2 ve kronik hastalığı olmayan \%37,9), savaş unsuru ile ilişkilendirme (kronik hastalığı olan\%22,1 ve kronik hastalığı olmayan \%31), spiritüel bakış algısı ile ilişkilendirme (kronik hastalığı olan \%13 ve kronik hastalığ 1 olmayan \%13,8), diğer hastalıklar ile ilişkilendirme (kronik hastalığı olan \% 11,7 ve kronik hastalığ1 olmayan \%6,9) ve COVID-19 belirtileri ile ilişkilendirme (kronik hastalığı olan \%9,1 ve kronik hastalığı olmayan \%6,9) kategorileridir. Diğer kategorilerde farklılıkların yer aldığı doğa olayları ile ilişkilendirme (kronik hastalığı olan \%6,5) ve öğreticilik ve eğitim ile ilişkilendirme (kronik hastalı̆̆ olan \%5,2)kategorilerinde ise kronik hastalığı olmayan yaşlı bireylerin ifade ettikleri metafor bulunmamaktadır. Son olarak diğer canlılar ile ilişkilendirme (kronik hastalığ olan \% 1,3 ve kronik hastalığ 1 olmayan \%3,4) kategorisinde ifade edilen metaforlar, benzer olarak kronik hastalığı olan ve olmayan katılımcilarda son sırada yer almaktadır.

\section{Tartışma}

Pandemi sürecinde yaşlı bireylerin COVID-19 kavramına ilişkin risk algılarını ve hastalığın anlamını belirlemek morbidite ve mortalite açısından önemli bir psikososyal hedefi oluşturmaktadır. Bu araştırma sonuçları dezavantajlı grup olarak nitelendirilen yaşlı bireylerin pandemi ile mücadeleyi nasıl algıladıkları, nasıl yönettikleri ve uyum süreçleri hakkında ipuçları vermektedir. Yaşlı bireylerin "COVID-19" kavramına ilişkin ürettikleri 41 farklı metafor belirlenmiştir. Araştırmada yer alan 106 katılımcının (\%85,5) COVID-19 kavramına ilişkin algılarını metafor yoluyla açiklayabildikleri belirlenmiştir. Katılımcların ürettikleri COVID-19 metaforları öncelikli olarak algıları ve nedenlerine göre 8 ana temada kategorize edilmiş ve sonra kronik hastalığa sahip olma değişkenine göre karşılaştırması yapılmıştır.

Yaşlı bireylerin en sık tanımladıkları (ikiden fazla tanımlanan) COVID-19 metaforları sırasıyla; mikrop, ölüm, görünmeyen düşman, 
ceza, boğulma, sinanma/ecel sinavı, öksürük, kıyamet, öldürücü grip, silah, ölüm makinesi, şeytan, zehir, hapislik, öğretmen, istila, cüzzam, bomba, afet, katliam şeklindedir. Yaşlı bireylerin en az kullandıkları COVID-19 metaforları ise; verem, karanlık, biyolojik terörist, uçan akrep, iflas, yangın, tehlikeli diken, hırsız, fırtına, kanser, yok edici, çı̆̆ düşmesi, insan kapanı, mıknatıslı virüs, körlük, komutan, veba, gezgin, kabus, arınma ve disiplin cezası' dır.

Yaşlı bireylerin kronik hasta olma değişkenine göre ürettikleri metafor kategorileri ele alındığında frekans sıklıklarına göre ilk sıralarda yer alan; sağlıklı yaşamı tehdit eden olumsuz unsur ile ilişkilendirme, savaş unsuru ile ilişkilendirme, spiritüel bakış algısı ile ilişkilendirme, diğer hastalıklar ile ilişkilendirme ve COVID-19 belirtileri ile ilişkilendirme kategorileri benzer olarak belirlenmiştir. Diğer doğa olayları ile ilişkilendirme ve öğreticilik ve eğitim ile ilişkilendirme kategorilerinde ise farklı olarak kronik hastalığı olmayan yaşlı bireylerin ürettikleri metafor bulunmamaktadır. Ancak kronik hastalığı olan ve olmayan yaşlı bireylerde benzer olarak son sırada yer alan diğer canlılar ile ilişkilendirme kategorisi belirlenmiştir.

Araştırma sonuçlarına göre en sık tanımlanan "sağlıklı yaşamı tehdit eden olumsuz unsur ile ilişkilendirme" kategorisinde; mikrop, ölüm, şeytan, zehir, hapislik, karanlık, iflas, yangın, hırsız, mıknatıslı virüs, kabus, hastalık taşıyan gezgin ve körlük metaforları yer almaktadır. Bu kategoride üretilen metaforların gerekçeleri incelendiğinde COVID19 'un insan yaşamını ciddi anlamda tehdit eden veya sonlandıran nitelikte algılandığ 19 ile özdeşleştirdikleri algıların oluşumunda, medya gündeminden düşmeyen artan vaka ve ölüm haberlerinde yüksek riskli grup olarak nitelendirilen 65 yaş ve üstü bireylere yapılan atıfların etkili olduğu düşünülmektedir. Ölümle sonuçlanan COVID-19 olgularını çoğunlukla yaşlı nüfusun oluşturması ve tıbbi komorbiditesi olan bireylerde sürecin öldürücü olması araştırma sonuçlarının yorumlanmasında gerekçe oluşturmaktadır. Zira araştırma katılımcılarının tamamını yaşlı nüfus ve 77 'sini $(\% 72,6)$ kronik hastalığı olan bireyler oluşturmaktadır. Ayrıca pandemi sürecinde "yaşlılar için riskli" vurgusu küresel ve toplumsal söylemlerde "tehlikeli yaşlı" şeklindeki algı ile yer değiştirmiştir. Tüm 
bu faktörlerin yaşlı bireylerin COVID-19 algılarının oluşumunda etkili olduğu düşünülmektedir.

Literatürde yer alan çalışmalarda yaşlı nüfusun damgalanmasına dönüşen bu durumun, yaşlı nüfus üzerinde bırakacağ ${ }_{1}$ etkilerin en az pandemi kadar yıkıcı olacağı öngörülmektedir (Türk, 2020; Previtali vd., 2020). Yaşlı bireylerin COVID-19'un potansiyel yıkıcı etkilerinin yanında COVID-19 hastalığına yakalanma yüksek riski algılarının davranışsal olarak stres, panik, kaygı gibi problemlere neden olabileceği düşünülmektedir. Literatürde yer alan bazı tahminler ruh sağlığı nedenli ölümlerin COVID-19 kaynaklı ölüm ile kıyas edilebileceğini göstermektedir (Bohlken vd., 2020). Türkiye'de 65 yaş üstü bireyler ile yapılan bir anket çalışmasında $(\mathrm{n}=1.304)$, yapılan haber ve paylaşımların yaşlıları olumsuz etkilediği \%59'luk bir oranla ortaya konulmuştur (Özdemir, 2020).

Araştırmada "savaş unsuru ile ilişkilendirme" kategorisinde üretilen metaforlar; görünmeyen düşman, silah, ölüm makinesi, istila, bomba, katliam, biyolojik terörist, yok edici, insan kapanı ve komutan şeklinde sıralanmaktadır. 17.yüzyıldan itibaren hastalık söylemlerinde geleneksel kullanımı olan savaş metaforlarının, Covid- 19 salgınında medya ve politik söylemlerdeki yaygın kullanımı dikkat çekmektedir (Isaacs and Priesz, 2020; Semino, 2021). Bu bağlamda araştırma sonuçlarının medyada ve politikacıların söylemlerinde yer alan, "bilinmeyen ve tehlikeli bir düşman" "uzun bir savaş" gibi daha çok COVID-19 ile başetme şeklindeki metafor örnekleri ile örtüştüğü belirlenmiştir (Salih Mohamed, 2021; Semino, 2021). Katılımciların ürettikleri savaş metaforlarında daha çok COVID-19'u güçlü ve yenilmez kılan algıların yer aldığı dikkat çekmektedir. Bu algı doğrultusunda kullanılan savaş metaforlarının rutin ve yoğun kullanımlarının sosyal ve kişisel refah için risk oluşturduğu ve olumsuz sonuçlara yol açabileceği düşünülmektedir. Savaş metaforlarının kaderciliği artırdığı ve insanların kendilerini sınırlayıcı davranışlarda bulunma istekliliğini azalttığı belirtilmektedir (Semino, 2021). Zira salgın hastalıklarda savaş metaforlarının kullanım tehlikesine dikkat çeken araştırmalar savaş metaforunun önyargısı, şiddet eğilimi, bedeni bir savaş alanı olarak görmesi, kaybetme ve yenilgi olasıllı̆̆1 eleştirilmektedir (Flusberg vd., 2018; Salih Mohamed, 2021). 
Araştırmada "spiritüel bakış algısı ile ilişkilendirme" kategorisinde ceza, sinanma/ecel sinavı, kıyamet, arınma metaforları yer almaktadır. Yaşlı bireyler tarafından COVID-19'un dini ve ruhani olarak algılandığı ve değerlendirildiği görülmektedir. İnsanoğlu, ilk çağlarda salgın hastalıkların nedenini anlayamadığı için salgın hastalıkları ve salgından kaynaklı ölümleri Tanrı cezası veya kötü ruhlar olarak algılamıştır. Bu felaketlerin önlenmesi için tapinaklarda tanrılarına dua etme ve kurbanlar verme ile önlem almaya çalışmışlardır (Yumul, 2021). Hatta ortaçağda Avrupa'da Tanrı gazabı olarak değerlendirilen Kara Veba hastalığı günahkârlara ceza olarak kabul edilmiştir. Bazı inanışlarda hastalıkları önlemenin yani beden ve ruhun arınması için çekilen acının önüne geçilmesinin Tanrı'ya karşı gelmekle aynı manaya geldiği vurgulanmıştır. O dönemde günahkâr olarak kabul ettikleri veba hastalarına "Flagellant" denen kırbaççılar tarafından toplum içinde fiziksel cezaların uygulandığı bilinmektedir (Tapısız and Altınbaş, 2020). Halbuki günümüzde salgınların nedeni çoğunlukla ekosistemi rahatsız eden doğa olayları ve insan faaliyetlerine patojenlerin gösterdikleri tepkiler olarak kabul edilmektedir (Platto vd., 2021). Ancak yaşlı bireylerin bazılarında salgının nedeni olarak Tanrı tarafından gönderilen bir ceza, sınav, arınma algısının yer aldığı belirlenmiştir. Yaşlı bireylerin COVID-19 salgınını Tanrı'nın takdiri olarak algılamaları tevekkülü doğururken, kaçış ve korunmanın mümkün olmadığı algısını da beraberinde getirebilmektedir. Bu bakış açısı yaşlı bireylerin korunma tedbirlerini ve salgınla mücadeleyi bırakmalarına sebep olabilecek riski taşımaktadır.

Araştırmada "diğer hastalıklar ile ilişkilendirme" kategorisinde öldürücü grip, cüzzam, verem, kanser, veba metaforları yer almaktadır. $\mathrm{Bu}$ sonuçlar, asırlarca birçok medeniyet tarafından varoluşsal bir tehdit olarak görülmüş salgın ve amansız hastalıkların, kendilerini hatırlattığ 1 ve metaforlarda yerini aldığını göstermektedir. Literatürde amansız hastalık söyleminde kullanılan verem ve kanser gibi hastalık tabularının sağlığ1 olumsuz etkilediği belirtilmektedir (Aykutalp, 2021; Craig, 2020; Güven, 2016; MacLeod, 2021). Ar1 ve Arslan (2020) ortaokul öğrencilerinin COVID-19 kavramına ilişkin metafor çalışmalarında "diğer hastalıklar ile ilişki" kategorisinde; grip, sars, bronşit, sigara, mers, gıcık şeklinde metaforlar elde etmişlerdir. Araştırmamız ile aynı 
kategoride farklı metaforların üretilmesi, ortaokul öğrencileri ve yaşlı bireylerin COVID-19 algılarının farklılığına işaret etmektedir. Ortaokul öğrencilerinin dile getirdikleri diğer hastalıklar ile ilişkilendirmede çaresiz bir hastalık algısının şekillenmediği, yaşlı bireylerin ise COVID19 algısında çaresizlik ve tedavi edilemez algıları olduğu ortaya çıkmaktadır.

Araştırmada "COVID-19 belirtileri ile ilişkilendirme" kategorisinde boğulma ve öksürük metaforları yer almaktadır. Literatürde tıbbi kayıtlara dayanarak COVID-19 klinik semptomlarına yönelik yapılan araştırmalarda, bu salgının olgu bildirimlerinde en sık; ateş, kuru öksürük, bulantı-kusma, yorgunluk gibi yakınmaların olduğu belirtilmektedir.(Fu vd., 2020; Guan vd. 2020) Yaşlı bireylerin bu kategorideki metafor algılarını, COVID-19 medya ve kamu spotu haber görüntüleri ile özdeşleştirmiş olabilecekleri düşünülmektedir. Nitekim Yeşilyurt (2021), COVID-19 kamu spotlarını ele aldığı araştırmasında, hijyen kurallarına uyumun yanında farkındalık ve genel bilgilendirme amaçlı yapılan ateş, öksürük, nefes darlığı, zatürre ve böbrek yetmezliği yaşayan COVID-19 olgularına sıklıkla yer verildiğini belirtmektedir. Araştırma katılımcılarının ürettikleri bu metaforlarda yapılan kamu spotlarının etkili olduğu ve tedbirli davranmalarına sebep olabilecek algiların oluştuğu düşünülmektedir.

Araştırmada kronik hastalığı bulunmayan yaşlı bireylerin "doğa olayları ile ilişkilendirme" ve "öğreticilik ve eğitim ile ilişkilendirme" kategorilerinde metafor üretmedikleri görülmektedir. Kronik hastalığ 1 olan yaşı bireyler ise doğa olayları ile ilişkilendirme kategorisinde; afet, fırtına ve çı̆̆ düşmesi metaforlarını, öğreticilik ve eğitim ile ilişkilendirme kategorisinde ise; öğretmen ve disiplin cezası metaforlarını oluşturmuştur.

Saatcı ve Murat (2020) üniversite öğrencileri ile yaptıkları COVID-19 metafor çalışmasında, bizim araştırma sonuçlarımız ile kısmen örtüşen doğa olayları ile ilgili kategoride; şimşek, Çanakkale'nin havası, sel, afet, yabani, ateş ve deprem metaforlarını elde etmiştir. Ayrıca üniversite öğrencilerinin bu kategoride oluşturduğu metafor gerekçeleri ile bizim araştırmamızda yer alan yaşlı bireylerin metafor gerekçeleri benzerlik göstermektedir. Her iki araştırma katılımcıları da doğa olayları ile ilgili 
metaforların nedeni olarak COVID-19'un tıpkı doğa olayları gibi plansız aniden gelişmesi ve hızlı bir şekilde dünyaya yayılmasını göstermiştir.

Araştırmada kronik hastalığı olan katılımcıların öğreticilik ve eğitim kategorisinde yer alan metaforların nedenleri incelendiğinde, kronik hastalık yönetimlerine paralel olarak salgını insanlara yol gösterici disipline edici bir eğitim olarak algıladıkları belirlenmiştir. Bu bağlamda düşünüldüğünde katılımcıların COVID-19 kavramına ilişkin bu algılarının kronik hastalık ve salgın yönetiminde olumlu etki yaratabileceği söylenebilir. Saatcı ve Murat (2020) yaptıkları COVID-19 metafor çalışmasında ise eğitim ile ilgili kategoride; bilinmeyen bir problem ve okul metaforlarını elde etmiştir. Üniversite öğrencilerinin oluşturdukları metafor nedenleri bizim çalışma sonuçlarımızdan farklı olarak hiç bitmeyecek bir süreç olarak okul ve bilinmeyen problem olarak COVID-19 algıları belirtilmiştir.

Araştırmada "diğer canlılar ile ilişkilendirme" kategorisinde; COVID19 'un zarar verici özelliği ile özdeşleştirilen uçan akrep ve tehlikeli diken metaforları yer almaktadır. Dönmez ve Gürbüz (2020) üniversite öğrencilerinin COVID-19'a yönelik algılarını inceledikleri çalışmalarında; sağlık, yaşam alanı, doğa, hayat, yuva, korku, dünya, kuş, yaşam, okul, acl, ekonomi, alışveriş, çevre, deniz, endişe, huzursuzluk, psikolojinin bozulması, toplum, umutsuzluk, eğitim, iletişim şeklinde metaforlar elde etmişlerdir. Bu metaforlardan diğer canlılar ile ilişkilendirme niteliği taşıyan kuş metaforu dikkat çekmekle birlikte, çalışma sonuçlarımız ile örtüşmemektedir.

Araştırmanın bulguları ışığında yaşlı bireylerin COVID-19 kavramına ilişkin ürettikleri metaforların, COVID-19 hastalığına karşı verilecek mücadele hakkında açıklayıcı ve yön verici olduğu ortaya çıkmaktadır. Yaşlı bireylerin COVID-19'a ilişkin algılarının tehdit edici ve cesaret kırıcı şekilde olumsuz olduğu belirlenmiştir. Yaşlı bireylerin zihinlerinde oluşan bu algılar salgından korunmaları ya da pozitif olgu durumunda mücadele etmeleri konusunda engelleyici nitelik taşıyabilmektedir. Nitekim Daoust'un (2020) 27 farklı ülkede yaşlı bireylerin COVID-19'a tepkilerini ortaya koyduğu araştırması bu görüşü destekler niteliktedir (Daoust, 2020). Araştırmasında toplu taşıma ve sosyal etkinliklerden kaçınan yaşlı bireylerin, kendi kendine izolasyon ve tecrit açısından duyarlı olmadıklarını ortaya koymuştur. Ayrıca Daoust, yaşlı bireylerin 
önleyici tedbirlere uyum açısından, örneğin yüz maskesi takmak konusunda disiplinli olmadıklarını vurgulamıştır (Daoust 2020).

\section{Sonuç}

Sonuç olarak araştırma sonuçlarında yaşlı bireylerin COVID-19 kavramına ilişkin; sağlık ve yaşam alanlarına özgü olumsuz etkiler yaratan, korku ve kaygının hakim olduğu algılar yer almaktadır. Katılımcıların üzerindeki bu etkilerin ve buna uyarlanabilen yanıt verme yeteneklerinin, sahip oldukları sosyokültürel kaynaklar tarafından şekillendirildiği düşünülmektedir. $\mathrm{Bu}$ araştırma sonuçlarında yaşlı bireylerin COVID-19 hastalığını anlama ve yorumlama konusunda bilgi akışını sağlayan medya ve kamu spotlarının önemi ortaya çıkmaktadır. Bu nedenle COVID-19 hastalığının doğru algılanması ve salgının daha iyi kontrol edilmesine yönelik halka güncel, zamanında, doğru, şeffaf, kısa, basit ve anlaşılır şekilde bilgi sağlamak hayati önem taşımaktadır. Dolayısıyla COVID-19 salgını ile ilgili resmi ve güvenilir bilgiler sunan erişilebilir platformların kritik öneme sahip olduğu gözetilmelidir.

Ayrıca geçmişten geleceğe uzanan salgın hastalıkların gelecekte de yaşanacak olması muhtemeldir. Bu gerçek doğrultusunda küresel düzeyde kriz durumlarında hali hazırda karşılık verecek sağlık alt yapıları, sosyal politika oluşumları ve stratejileri geliştirilmelidir. Zira COVID-19 salgını, küresel sağlık otoriteleri dahil tüm dünya devletlerinin hazırlıksızlığı ve yetersizliğini gözler önüne sermiştir. 


\title{
EXTENDED ABSTRACT
}

\section{COVID-19 Metaphors: A Qualitative Study in Elderly Individuals in COVID-19 Pandemia

\author{
*
}

\author{
Mehtap Pekesen- Şengül Akdeniz \\ Akdeniz University
}

Although the COVID-19 disease can be seen in all age groups, the elderly population has drawn attention to the elderly population as the first cases resulting in death. The COVID-19 pandemic, which threatens the whole world and humanity physically, spiritually, and socially, still continues. While the fight against the pandemic continues globally, the fact that all this is caused by a virus has caused people to question the concept of "COVID19". In this process, different hypotheses have been developed about the virus, which is the causative agent of COVID-19 disease, which occurs with upper respiratory tract symptoms and has a high death potential. People are still trying to make sense of and understand the concept of COVID-19 in their minds to the extent of their own knowledge. It is common use to determine people's perceptions of making sense of a new concept through metaphor. The subject of this research is to question the perceptions of the elderly individuals, who are described as the disadvantaged group in the pandemic process, regarding the concept of COVID-19.

The research was conducted in order to determine the perceptions and reasons of the concept of "COVID-19" according to the chronic disease status of elderly individuals during the COVID-19 pandemic. Determining the risk perceptions of elderly individuals regarding the COVID-19 concept constitutes an important psychosocial goal in terms of morbidity and mortality.

Within the scope of the research, metaphors were used as a tool to reveal the ideas of elderly individuals about the epidemic. This qualitative study was conducted with individuals aged 65 and over living in different regions of Turkey. A total of 124 elderly individuals with and without chronic disease were included in the study by means of easily accessible sampling, which is a purposeful sampling method. Research version obtained by telecommunication in June-July 2020. Qualitative data were collected in the form of in-depth interviews through the metaphorical perception form created by the researchers. In the study, revealing the perceptions of elderly 
individuals on the concept of "COVID-19" according to their chronic illness and its reasons is like "COVID-19 ..... Because..." sentences were asked to complete. The concept of "because" was used to provide a justification or a basis for the metaphors produced by the participants in the research.

SPSS 21 package program and content analysis were used in the analysis of the research data. While analyzing the data obtained from elderly individuals within the scope of the research, primarily metaphor forms were examined and checked. Eighteen interviews, which did not provide any logical basis or justification for the metaphor and were thought to not contribute to the understanding of the perception of COVID-19 disease, were not included in the study.

It was determined that 106 participants $(85.5 \%)$ in the study were able to explain their perceptions of the concept of COVID-19 through metaphor. 41 different metaphors produced by elderly individuals regarding the concept of "COVID-19" were determined. The COVID-19 metaphors produced by the participants were primarily categorized into 8 main themes according to their perceptions and reasons and then compared according to the variable of having a chronic disease.

The most frequently defined (more than two) COVID-19 metaphors by the elderly are respectively; germ, death, invisible enemy, punishment, suffocation, ordeal, cough, doomsday, lethal flu, weapon, death machine, devil, poison, prison, teacher, invasion, leprosy, bomb, disaster, massacre. The least used COVID-19 metaphors by elderly people are; tuberculosis, darkness, biological terrorist, flying scorpion, bankruptcy, fire, dangerous thorn, thief, storm, cancer, exterminator, avalanche, human trap, magnet virus, blindness, commander, plague, wanderer, nightmare, purification and disciplinary punishment' is.

Considering the metaphor categories produced by elderly individuals according to the variable of being chronically ill, the ones that rank first in terms of frequency are; The categories of associating with the negative element threatening healthy life, associating with the element of war, associating with the perception of spiritual perspective, associating with other diseases and associating with the symptoms of COVID-19 were determined to be similar. On the other hand, in the categories of associating with other natural events, teaching and associating with education, there are no metaphors produced by elderly individuals who do not have chronic diseases. However, in elderly individuals with and without chronic diseases, 
the category of association with other living things, which is in the last place, was determined similarly.

These results give clues about how elderly individuals, who are regarded as disadvantaged groups, perceive and manage the pandemic and adapt to the fight against this epidemic. According to the results of the research, it is revealed that the metaphors produced by the elderly individuals regarding the concept of COVID-19 are explanatory and guiding about the fight against the COVID-19 disease. It has been determined that elderly individuals' perceptions of COVID-19 are threatening and discouragingly negative. These perceptions formed in the minds of elderly individuals can be a hindrance for them to protect themselves from the epidemic or to fight in the case of a positive case.

It is thought that the references made to individuals aged 65 and over, who are described as a high-risk group, in the news of increasing cases and deaths that do not fall on the media agenda, are effective in the formation of perceptions that elderly individuals identify with COVID-19 in their minds. The fact that the cases of COVID-19 resulting in death are mostly composed of the elderly population and that the process is lethal in individuals with medical comorbidities constitute the reason for the interpretation of the research results. Because all of the research participants are elderly population and $77(72.6 \%)$ of them are individuals with chronic diseases. In addition, the emphasis of "risky for the elderly" during the pandemic process has been replaced by the perception of "dangerous elderly" in global and social discourses. All these factors are thought to be effective in the formation of COVID-19 perceptions of elderly individuals.

The results of this research reveal the importance of media and public service announcements that provide information flow for elderly individuals to understand and interpret the COVID-19 disease. For this reason, it is vital to provide the public with up-to-date, timely, accurate, transparent, concise, simple and understandable information for the correct detection of the COVID-19 disease and better control of the epidemic. Therefore, it should be considered that accessible platforms that provide official and reliable information about the COVID-19 outbreak are of critical importance.

In addition, it is possible that epidemic diseases from the past to the future will also be experienced in the future. In line with this fact, health infrastructures, social policy formations and strategies should be developed 
to respond to crisis situations at the global level. Because the COVID-19 outbreak has revealed the unpreparedness and inadequacy of all world states, including global health authorities.

\section{Kaynakça / References}

Arapoğlu, F. (2020).Sanatta konu olarak hastalık. Aurum Sosyal Bilimler Dergisi, 5(1), 82-86.

Aykutalp, A. (2021).Geç Modern çă̆da gündelik hayat ve kamusal karşılaşma: COVID-19 salgınının sosyolojisi üzerine bir analiz. In: Ceylan, A.Ç., Özbay, F., Özomay, Z., Kurt, M.B. (Ed.) Sosyal ve Beşerî Bilimlerde Araştırma ve Değerlendirmeler, Cilt 1. 1.rd edn. Gece KitaplığıYayınları, Ankara, 221-236. Erişim Tarihi 03.05.2021 https://philpapers.org/archive/AYKGMA.pdf.

Bohlken, J., Schömig, F., Lemke, M.R., Pumberger, M. and Riedel-Heller, S.G. (2020) COVID-19 Pandemic: Stress experience of healthcare workers. Psychiatr Prax, 47(4), 190-197.

Budak, F. ve Korkmaz, Ş. (2020). COVID-19 pandemi sürecine yönelik genel bir değerlendirme: Türkiye örneği. Sosyal Araştırmalar ve Yönetim Dergisi, 1, 62-79.

Craig, D. (2020). Pandemic and its metaphors: Sontag revisited in the COVID19 era. European Journal of Cultural Studies, 23(6), 1025-1032. https://doi.org/10.1177/1367549420938403.

Creswell, J.W. (2020). Nitel araştırma yöntemleri: Beş yaklaşıma göre nitel araştırma ve araştırma deseni. Çev. Ed.Bütün, M. ve Demir, S.B. 5. Baskı, Ankara: Siyasal Kitabevi.

Daoust, J.F. (2020). Elderly people and responses to COVID-19 in 27 Countries. PloS one, 15(7): e0235590. https://doi.org/10.1371/journal.pone.

D'cruz, M. ve Banerjee, D. (2020). 'An invisible human rights crisis': The marginalization of older adults during the COVID-19 pandemic-An advocacy review. Psychiatry research, 292, 113-369 https://doi.org/10.1016/j.psychres.2020.113369.

Dönmez, İ. ve Gürbüz, S. (2020) Üniversite öğrencilerinin COVID-19 virüsü hakkında bilişsel yapılarının belirlenmesi. Manas Sosyal Araştırmalar Dergisi, 9(4), 2159-2172.

Flusberg, S.J., Matlock, T., Thibodeau, P.H. (2018). War metaphors in public discourse. Metaphor and Symbol, 33(1), 1-18. 
Fu, L., Wang, B., Yuan, T., Chen, X., Ao, Y., Fitzpatrick, T. and Zou, H. (2020). Clinical characteristics of coronavirus disease 2019 (COVID-19) in China: A systematic review and meta-analysis. Journal of Infection, 80(6), 656-665.

Guan, W.J., Ni, Z.Y., Hu, Y., Liang, W.H., Ou, C.Q., He, J.X and Zhong, N.S. (2020). Clinical characteristics of coronavirus disease 2019 in China. New England journal of medicine, 382(18), 1708-1720.

Güven, D.Ç. (2016). Dünya edebiyatında" Amansız Hastalık" söylemi--Sontag, Karatani Ve Dumas Fils Örneklerinde. Electronic Turkish Studies, 11(4).

Isaacs, D. ve Priesz, M,A, (2020). Covid-19 and the metaphor of war. Journal of Paediatrics and Child Health, 57(2021), 6-8.

Kılcan, B. (2017). Metafor ve eğitimde metaforik çalışmalar için bir uygulama rehberi. Ankara: Pegem Akademi.

MacLeod, N. (2021). COVID-19 metaphors. Critical Inquiry, 47(2), 49-51.

Miles, M.B. ve Huberman AM (2016). Nitel veri analizi. Çev. Ed. Akbaba Altun, S. ve Ersoy, A. Ankara: Pegem Akademi.

Özdemir, M. (2020) Yaşlılık algısının koronavirüs salgını sürecindeki kültürel değişimi. Milli Folklor, 16(127), 46-58.

Platto. S., Wang, Y., Zhou, J. ve Carafoli, E. (2021). History of the COVID-19 pandemic: Origin, explosion, worldwide spreading. Biochemical and biophysical research communications, 538, 14-23.

Previtali, F., Allen, L.D. ve Varlamova, M. (2020). Not Only Virus Spread: The Diffusion of Ageism during the Outbreak of COVID-19. Journal of Aging \& Social Policy 32(4-5), 506-514.

Saatc1, G.,Murat, A.K.S.U. (2020). Lisans düzeyinde turizm eğitimi alan yabancı uyruklu öğrencilerin koronavirüs algılarını metafor yolu ile tespit etmeye yönelik bir araştırma. Journal Of Awareness, 5(4), 617-630.

T.C. Sağlık Bakanlığı, (2021). COVID-19 (SARS-CoV-2 Enfeksiyonu) Rehberi. 23 Eylül 2021 tarihinde, https://Covid19bilgi.saglik.gov.tr/depo/rehberler/COVID-19 Rehberi.pdf adresinden erişildi.

Salih Mohamed. H.A. (2021). COVID-19 Pandemisi haberlerinde savaş metaforu kullanımının eleştirel analizi. HABITUS Toplumbilim Dergisi, 2(2), 33-53.

Semino, E. (2021). Not Soldiers but Fire-fighters-Metaphors and COVID-19. Health Communication, 36(1), 50-58.

Şahan, K. (2017) Metafor ne değildir? Kesit Akademi Dergisi, 3(8), 166-176. 
Tapısız, Ö.L. ve Altınbaş, S.K. (2020). Mikroorganizmalar mavi gezegende bizden çok önce vardı: Pandemiler tarihi. Türk Kadın Sağhlğı ve Neonatoloji Dergisi, 2(2), 53-69.

Tekindal, M. ve Uğuz Arsu, Ş. (2020). Nitel araştırma yöntemi olarak fenomenolojik yaklaşımın kapsamı ve sürecine yönelik bir derleme. Ufkun Ötesi Bilim Dergisi, 20(1), 153- 182.

Türk, A. (2020). Koronavirüs (COVID-19) Pandemisi sürecinde yaşlılara yönelik uygulamalar ve yaşlıların psiko-sosyal durumu üzerine bir değerlendirme. Sosyal Hizmet, 35-46.

Üstün, Ç. ve Özçiftçi, S. (2020). COVID-19 pandemisinin sosyal yaşam ve etik düzlem üzerine etkileri: Bir değerlendirme çalışması. Anadolu Kliniği Tip Bilimleri Dergisi, 25(Special Issue on COVID 19), 142-153.

WHO, (2021). Coronavirus disease 2019 (COVID-19) Situation Report 23 Eylül 2021 tarihinde, https://www.who.int/emergencies/diseases/novelcoronavirus-2019/situation-reports adresinden erişildi.

Yeşilyurt, Ö. (2021) COVID-19 Pandemi sürecinin yönetilmesinde sosyal pazarlama aracı olarak kamu spotlarının incelenmesi: İçerik analizi. OPUS Uluslararası Toplum Araştırmalarn Dergisi, 17(Pandemi Özel Say1s1), 3475 - 3505.

Yıldırım, A., Şimşek, H. (2018). Sosyal bilimlerde nitel araştırma yöntemleri. Ankara: Seçkin Yayıncllık.

Yumul, A. (2021)Yine bir salgın, yeni bir salgın. İnsan ve İnsan Dergisi, 8(28), 13-31.

\section{Kaynakça Bilgisi / Citation Information}

Pekesen, M. ve Akdeniz, Ş. (2021). COVID-19 metaforları: COVID-19 Pandemisinde yaşlı bireyler üzerine nitel bir çalışma. OPUSUluslararası Toplum Araştırmaları Dergisi, 18(43), 6394-6424. DOI: 10.26466/opus.936487. 